\title{
A systematic review of the scalp donor site for split- thickness skin grafting
}

\author{
Suk Joon Oh \\ Department of Burn Reconstructive Surgery, Bestian Seoul Hospital, Seoul, Korea
}

Split-thickness skin grafting (STSG) is the gold standard for coverage of acute burns and reconstructive wounds. However, the choice of the donor site for STSG varies among surgeons, and the scalp represents a relatively under-utilized donor site. Understanding the validity of potential risks will assist in optimizing wound management. A comprehensive literature search was conducted of the PubMed database to identify studies evaluating scalp skin grafting in human subjects published between January 1, 1964 and December 31, 2019. Data were collected on early and late complications at the scalp donor site. In total, 27 articles comparing scalp donor site complications were included. The selected studies included analyses of acute burn patients only (21 of 27 articles), mean total body surface area (20 of 27), age distribution (22 of 27), sex (12 of 27), ethnicity (5 of 27), tumescent technique (21 of 27), depth setting of the dermatome (24 of 27), number of harvests (20 of 27), mean days of epithelization (18 of 27), and early and late complications ( 27 of 27 ). The total rate of early complications was 3.82\% (117 of 3,062 patients). The total rate of late complications was 5.19\% (159 of 3,062 patients). The literature on scalp skin grafting has not yet identified an ideal surgical technique for preventing donor site complications. Although scalp skin grafting provided superior outcomes with fewer donor site complications, there continues to be a lack of standardization. The use of scalp donor sites for STSG can prevent early and late complications if proper surgical planning, procedures, and postoperative care are performed.

Keywords Scalp / Wound healing / Skin transplantation / Systematic review

\author{
Correspondence: Suk Joon Oh \\ Department of Burn Reconstructive \\ Surgery, Bestian Seoul Hospital, 429 \\ Dogok-ro, Gangnam-gu, Seoul 06208, \\ Korea \\ Tel: +82-70-7609-9321 \\ Fax: $+82-70-7005-4233$ \\ E-mail:sjoh46@nate.com
}

Received: March 24, $2020 \bullet$ Revised: July 2, $2020 \bullet$ Accepted: July 15, 2020

pISSN: 2234-6163 • elSSN: 2234-6171 • https://doi.org/10.5999/aps.2020.00479 • Arch Plast Surg 2020;47:528-534

\section{INTRODUCTION}

The scalp skin graft was first applied to the abdomen and loins in 1964 by Crawford. A 9-year-old girl sustained deep burns extending from the mid-calf to the nipple, and thin skin strips of the shaved scalp were harvested with a large-bladed scalpel (Crawford 1964) [1]. Since then, many authors have reported scalp skin grafts for acute burn wounds, trauma, and surgical wounds [2-27]. They also reported scarless wound healing at the scalp donor site after single or multiple harvests, as well as a small number of complications. Herein, the author provides information on surgical techniques, management, and complications of scalp skin grafting through a review of the literature.

\section{METHODS}

References were identified though a literature search, as well as personal knowledge and special searches for related articles using an electronic database. Articles were primarily retrieved from PubMed (with the publication date limited to 01/01/1964- 


\section{Fig. 1. Flowchart for search strategy}

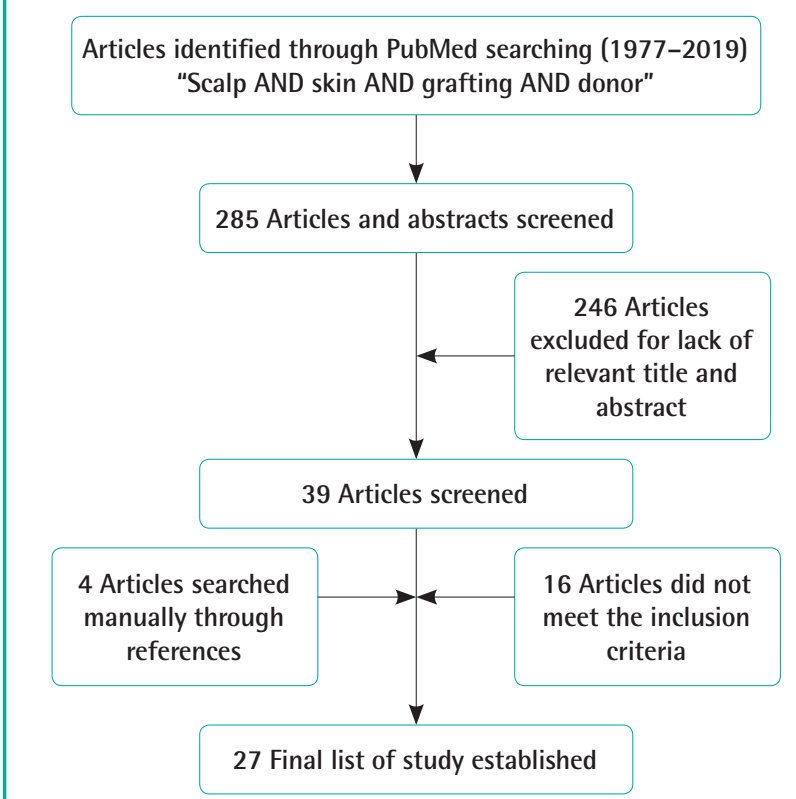

$12 / 31 / 2019)$, and additional articles were identified through other sources (i.e., manual searching of references). The following keywords and combinations of free text were included: scalp AND skin AND grafting AND donor. The search was limited to English and to research on human subjects. The exclusion criteria were literature reviews and correspondence to editors. In the initial literature search, a total of 290 articles were identified. Articles with no information about complications, fewer than six cases, and no available full text were excluded, and 27 studies were obtained (Fig. 1). Data were extracted on patient characteristics (e.g., number of patients, age, sex, cause of the recipient, total body surface area [TBSA]), operation characteristics (e.g., scalp preparation, tumescent solution, the depth setting of the dermatome, the number of harvests, the interval of harvests), duration of healing of the scalp donor site, complications, outcomes, and possible additional determinants. The final search was completed in January 2020.

\section{INDICATIONS OF GRAFTS}

In 21 of the 27 articles, acute burn patients were treated with a scalp split-thickness skin graft (STSG); only acute burn patients (51.6\%, 1,580 of 3,062 patients) were included in 14 of 21 articles $[2,6-11,13,14,18,19,22,26,27]$, while the other seven of these 21 articles also included patients with postburn scars, trauma, reconstructed wounds, and other patients $(34.6 \%$, 1,058 of 3,062 patients) $[3-5,12,15,23,28]$. The other six articles without acute burn patients (13.8\%, 424 of 3,062 patients) reported scalp STSG in 30 plastic surgery patients [16], 181 elderly patients with chronic ulcers and large skin defects $[17,24]$, 58 patients with oncologic defects [25], and 155 patients with otologic defects [20,21] (Table 1).

The mean TBSA of acute burn patients was greater than $30 \%$ in eight articles $[2,7,8,11-14,26]$ and less than $30 \%$ in six articles $[3,10,18,19,23,27]$. Seven articles $[4-6,9,15,22,28]$ did not report the mean TBSA (Table 1).

\section{AGE AND SEX DISTRIBUTION}

Seven studies included patients under the age of 16 years [3,9, $10,12,14,22,26], 11$ included children and adults $[4-8,11,18,21$, $23,24,28]$, and five were adults-only $[15,17,19,25,27]$. Four articles $[2,13,16,20]$ did not mention age (Table 1 ).

The mean age of the patients in the 20 articles that included that information was 23.6 years. The mean age of the patients was 5.13 years in the nine articles with children $[3,8-10,12,14$, $22,26,27], 27.67$ years in the seven articles with children and adults $[5-7,11,18,23,28]$, and 59.08 years in the four articles with adults. Seven articles $[2,4,13,16,20,21,24]$ did not mention the mean age (Table 1).

In terms of sex distribution, male patients were predominant in most articles [11,14,15,17-19,22-25], except for two articles $[5,28]$. Fifteen articles did not mention the sex distribution.

\section{ETHNICITY}

Patients' ethnicity was noted in five articles $[2,12,15,18,26]$. Only one article, by van Niekerk et al. [26], reported a high incidence of complications at the scalp donor site in nine Black Africans with hair types VI-VIII and five patients of mixed races with hair types III-V among 25 patients. Four other articles included African American, northern African, and Hispanic or Asian individuals. However, they did not note the rate of complications at the scalp donor site related to ethnicity.

\section{HARVESTING TECHNIQUE}

Patients' heads were shaved on the day before surgery or the morning of surgery. Many articles reported that patients' heads were shaved using a razor. It is difficult to remove the hair shaft from grafts; thus, the hair shaft was trimmed to a length of 1-2 $\mathrm{mm}$ to allow easier subsequent hair removal $[20,21]$.

In eight articles $[2,3,8,9,11,14,23,27]$, the tumescent solution contained only normal saline or Ringer's lactate. The tumescent solution in four articles was mixed with anesthetic agents, such 
Table 1 . Summary of review articles

\begin{tabular}{|c|c|c|c|c|c|c|c|c|}
\hline Author (year) & $\begin{array}{l}\text { No. of } \\
\text { patients }\end{array}$ & Age $^{a)}$ & $\begin{array}{c}\text { Indications of } \\
\text { graft }\end{array}$ & $\begin{array}{c}\text { Harvests } \\
\text { (No. of patients) }\end{array}$ & $\begin{array}{l}\text { Depth setting } \\
\text { of dermatome } \\
\text { (inch) }\end{array}$ & $\begin{array}{l}\text { Epithelization } \\
\text { (day) }\end{array}$ & $\begin{array}{c}\text { Early } \\
\text { complications } \\
\text { (No./total No./\%) }\end{array}$ & $\begin{array}{c}\text { Late } \\
\text { complications } \\
\text { (No./total No./\%) }\end{array}$ \\
\hline $\begin{array}{l}\text { Taylor et al. } \\
\text { (1977) [2] }\end{array}$ & 26 & None & Acute burn & $\begin{array}{c}\text { Single (17) and } \\
\text { multiple (9) }\end{array}$ & $0.006-0.015$ & $7-8$ & None & $\begin{array}{c}\text { Forehead scars } \\
(3 / 3 / 11.54)\end{array}$ \\
\hline $\begin{array}{l}\text { Kloti and Pochon } \\
\text { (1981) [3] }\end{array}$ & 31 & 4.7 yr (5 mon-15 yr) & $\begin{array}{l}\text { Acute burn and } \\
\text { trauma }\end{array}$ & $\begin{array}{c}\text { Single (16) and } \\
\text { multiple (15) }\end{array}$ & $0.002-0.043$ & $12-14$ & $\begin{array}{l}\text { Staph. infection } \\
(1 / 1 / 3.2)\end{array}$ & $\begin{array}{l}\text { Alopecia (5), HS (1); } \\
\quad(6 / 19.35)\end{array}$ \\
\hline $\begin{array}{l}\text { Berkowitz } \\
\text { (1981) [4] }\end{array}$ & 36 & None (7.5 mon-70 yr) & $\begin{array}{l}\text { Acute and } \\
\text { reconstructive } \\
\text { burn }\end{array}$ & Multiple (36) & $0.008-0.014$ & 5 & $\begin{array}{l}\text { Transient alopecia } \\
(3 / 3 / 8.3)\end{array}$ & Hair transfer (1/1/2.78) \\
\hline $\begin{array}{l}\text { Finucan et al. } \\
\text { (1984) [5] }\end{array}$ & 18 & $25.7 \mathrm{yr}(5-80 \mathrm{yr})$ & $\begin{array}{l}\text { Acute burn, } \\
\text { postburn scar, } \\
\text { excised wound, } \\
\text { trauma }\end{array}$ & Single & 0.012 & $5-6$ & Folliculitis (1/1/5.56) & Alopecia (1/1/5.56) \\
\hline $\begin{array}{l}\text { Lesesne and Rosenthal } \\
\text { (1986) [6] }\end{array}$ & 113 & 28 yr (3 mon-89 yr) & Acute burn & $\begin{array}{l}\text { Single (88) and } \\
\text { multiple (25) }\end{array}$ & None & None & $\begin{array}{l}\text { Staph. folliculitis (2), } \\
\text { crust (10); (12/10.6) } \\
\text { Hypotension }{ }^{\text {b) }}(1 / 1 / 0.9)\end{array}$ & Alopecia (7/7/6.19) \\
\hline $\begin{array}{l}\text { Zingaro et al. } \\
(1988)[7]\end{array}$ & 21 & 23.9 yr (2-63 yr) & Acute burn & $\begin{array}{l}\text { Single (13) and } \\
\text { multiple (8) }\end{array}$ & $0.011-0.017$ & None & $\begin{array}{l}\text { Serratia infection } \\
(1 / 1 / 4.76)\end{array}$ & Alopecia (1/1/4.76) \\
\hline Brou et al. (1990) [8] & 194 & 6.1 yr (1 mon-20 yr) & Acute burn & Multiple (194) & None & None & None & Alopecia (63/63/32.57) \\
\hline $\begin{array}{l}\text { Martinot et al. } \\
\text { (1994) [9] }\end{array}$ & 37 & $2.5 \mathrm{yr}(7 \mathrm{mon}-12 \mathrm{yr})$ & Acute burn & Single (37) & None & None & $\begin{array}{l}\text { Prolonged scab } \\
\qquad(4 / 4 / 10.81)\end{array}$ & Hair transfer (2/2/5.41) \\
\hline $\begin{array}{l}\text { Gyger et al. } \\
\text { (1996) [10] }\end{array}$ & 43 & $\begin{array}{l}5.75 \mathrm{yr} \\
\quad(9 \mathrm{mon}-15.5 \mathrm{yr})\end{array}$ & Acute burn & $\begin{array}{l}\text { Single (41) and } \\
\text { multiple (2) }\end{array}$ & 0.008 & 9.5 & Scab (22/22/51.16) & $\begin{array}{l}\text { Alopecia (2), technical } \\
\text { error (1); (3/6.98) }\end{array}$ \\
\hline $\begin{array}{l}\text { Chang et al. } \\
\text { (1998) [11] }\end{array}$ & 150 & $30.2 \mathrm{yr}(1-73 \mathrm{yr})$ & Acute burns & Single and multiple & $0.006-0.012$ & $\begin{array}{l}6.8 \text { (first } \\
\text { harvest)-9.2 } \\
\text { (second harvest) }\end{array}$ & Infection (4/4/2.67) & $\begin{array}{l}\text { Alopecia (4), technical } \\
\text { error (3), hair transfer } \\
\text { (1); (8/ 5.33) }\end{array}$ \\
\hline $\begin{array}{l}\text { MacLennan et al. } \\
\text { (1998) [12] }\end{array}$ & 109 & $5 \mathrm{yr} \pm 5.7 \mathrm{mon}$ & $\begin{array}{l}\text { Acute burn, } \\
\text { postburn scar }\end{array}$ & $\begin{array}{l}\text { Single }(75) \text { and } \\
\text { multiple (34) }\end{array}$ & $\begin{array}{l}0.008-0.015 \\
\quad(\text { mean } 0.013)\end{array}$ & None & None & $\begin{array}{l}\text { Alopecia (10), hair transfer } \\
\text { (18); (28/ 25.6) }\end{array}$ \\
\hline $\begin{array}{l}\text { Carter et al. } \\
\text { (1999) [13] }\end{array}$ & 56 & None & Acute burn (face) & Single & $\begin{array}{l}0.016-0.026 \text { thick } \\
\text { or } 0.010-0.018 \\
\text { thin }\end{array}$ & None & $\begin{array}{l}\text { Concrete scalp } \\
\text { deformity } \\
(18 / 18 / 32.14)\end{array}$ & Alopecia (8/8/14.29) \\
\hline $\begin{array}{l}\text { Barret et al. } \\
\text { (1999) [14] }\end{array}$ & 450 & $6.1 \pm 4.4 \mathrm{yr}$ & Acute burn & $\begin{array}{r}\text { Single (210) and } \\
\text { multiple (240) }\end{array}$ & $\begin{array}{l}0.010-0.014 \\
0.016 \text { for face }\end{array}$ & None & $\begin{array}{l}\text { Staph. folliculitis } \\
(8 / 8 / 1.78)\end{array}$ & Alopecia (10/10/2.23) \\
\hline $\begin{array}{r}\text { Mimoun et al. } \\
(2006) \text { [15] }\end{array}$ & 757 & $48 \mathrm{yr}$ & $\begin{array}{l}\text { Acute burn, } \\
\text { postburn scar, } \\
\text { others (25.4\%) }\end{array}$ & $\begin{array}{l}\text { Single (668) and } \\
\text { multiple (89) }\end{array}$ & 0.008 & $6.2-10.2$ & Folliculitis $(3 / 3 / 0.40)$ & Alopecia (8/8/1.06) \\
\hline $\begin{array}{l}\text { Khalid et al. } \\
\text { (2008) [16] }\end{array}$ & 30 & None & $\begin{array}{l}\text { Plastic surgery } \\
\text { patients }\end{array}$ & Single & $0.010-0.012$ & 6.7 & $\begin{array}{l}\text { Folliculitis (2), scab (1); } \\
\quad(3 / 10)\end{array}$ & $\begin{array}{l}\text { No alopecia, hair transfer } \\
\text { and HS }\end{array}$ \\
\hline $\begin{array}{l}\text { Weyandt et al. } \\
\text { (2009) [17] }\end{array}$ & 166 & $71 \pm 13$ yr (26-93 yr) & $\begin{array}{l}\text { Chronic ulcer and } \\
\text { large skin defect }\end{array}$ & Single & $0.008-0.012$ & 5.4 & $\begin{array}{l}\text { Severe folliculitis } \\
(3 / 3 / 1.81)\end{array}$ & $\begin{array}{l}\text { Alopecia (2), HS (1); } \\
\quad(3 / 1.81)\end{array}$ \\
\hline $\begin{array}{l}\text { Farina et al. } \\
\text { (2010) [18] }\end{array}$ & 295 & 24 yr (5 mon-78 yr) & Acute burn & $\begin{array}{l}\text { Single (225) and } \\
\text { multiple (70) }\end{array}$ & $0.005-0.007$ & 7 & Folliculitis (5/5/1.69) & $\begin{array}{l}\text { Alopecia (2), hair transfer } \\
\text { (3); (5/1.68) }\end{array}$ \\
\hline $\begin{array}{l}\text { Zakine et al. } \\
\text { (2012) [19] }\end{array}$ & 15 & 46.2 yr (25-79 yr) & Acute burn & Single & $\begin{array}{r}0.008 \text { skin and } \\
0.008 \text { dermis }\end{array}$ & 9.8 & None & No alopecia and scar \\
\hline $\begin{array}{l}\text { Goldsztein et al. } \\
\text { (2013) [20] }\end{array}$ & 144 & None & Otology/atresia & Single & $0.008-0.010$ & 21 & $\begin{array}{l}\text { Local infection } \\
(1 / 1 / 0.69)\end{array}$ & Alopecia (1/1/0.69) \\
\hline $\begin{array}{l}\text { Du and Zhang } \\
\text { (2014) [21] }\end{array}$ & 11 & None & Otology, trauma & Single & $0.008-0.010$ & None & No infection & $\begin{array}{l}\text { Scar (2), hair transfer (2); } \\
\quad(4 / 36.4)\end{array}$ \\
\hline $\begin{array}{l}\text { Wyrzykowski et al. } \\
\text { (2015) [22] }\end{array}$ & 123 & 2.98 yr (4 mon-15 yr) & Acute burn & $\begin{array}{l}\text { Single (121) and } \\
\text { multiple (2) }\end{array}$ & $0.008-0.012$ & $7-10$ & None & $\begin{array}{c}\text { Alopecia (2), pressure sore } \\
\text { (5), forehead scar (1), } \\
\text { HS (1); (9/7.32) }\end{array}$ \\
\hline $\begin{array}{l}\text { Roodbergen et al. } \\
\text { (2016) [23] }\end{array}$ & 93 & $2.25 \mathrm{yr}(2 \mathrm{mon}-66 \mathrm{yr})$ & Acute burn, others & Single & $0.008-0.012$ & $10-14$ & $\begin{array}{l}\text { Folliculitis (2), scab (1); } \\
\quad(3 / 3.23)\end{array}$ & No alopecia and HS \\
\hline $\begin{array}{l}\text { Voorman et al. } \\
\text { (2017) [24] }\end{array}$ & 15 & None (6-90 yr) & Facial defects & Single & $0.020-0.025$ & $5-7$ & None & No alopecia and HS \\
\hline $\begin{array}{l}\text { Kovacs et al. } \\
\text { (2017) [25] }\end{array}$ & 58 & 71.12 yr (24-91 yr) & Oncologic defect & Single & 0.012 & 7 & None & Alopecia (2/2/3.4) \\
\hline $\begin{array}{l}\text { van Niekerk et al. } \\
\text { (2018) [26] }\end{array}$ & 25 & $\begin{array}{l}5.7 \text { yr (4 mon-12 yr); } \\
\text { Black African (15) }\end{array}$ & Acute burn & $\begin{array}{l}\text { Single (5) and } \\
\text { multiple (20) }\end{array}$ & 0.008 & $11.2-19.2$ & $\begin{array}{l}\text { Folliculitis }(11 / 11 / 44) \\
\text { Non-healing wounds } \\
(13 / 13 / 52) \\
\text { Sepsis and death } \\
(5 / 5 / 20)\end{array}$ & Alopecia (4), HS (1); (5/20) \\
\hline $\begin{array}{l}\text { Neuhaus et al. } \\
\text { (2019) [27] }\end{array}$ & 32 & $7.3 \pm 4.5 \mathrm{yr}(1-15 \mathrm{yr})$ & Acute burn & Single and multiple & $0.006-0012$ & None & None & Alopecia (11/11/33.38) \\
\hline Oh (2019) [28] & 14 & 34.2 yr (5-56 yr) & $\begin{array}{l}\text { Acute burn and } \\
\text { postburn scar }\end{array}$ & Single & $\begin{array}{r}0.009 \text { skin and } \\
0.009 \text { dermis }\end{array}$ & 9.9 & Folliculitis (1/1/7.14) & $\begin{array}{l}\text { No alopecia, HS (1); } \\
\quad(1 / 7.14)\end{array}$ \\
\hline
\end{tabular}

HS, hypertrophic scar; Staph., Staphylococcus aureus.

${ }^{a}$ Mean (range) or mean \pm SD (range); ${ }^{b}$ Refers to early systemic complications. 
as $0.5 \%$ lignocaine [5], $0.25 \%-0.5 \%$ prilocaine [17], $1 \%$ prilocaine [25], and $0.06 \%$ bupivacaine [20]. Additionally, in 16 articles, the solutions were mixed with adrenaline [7] at ratios of $1: 10,000$ [25], 1:100,000 [12,16], 1:200,000 [5,17], 1:250,000 [22], 1:300,000 [14], 1:500,000 [18,22,26], 1:600,000 [21], $1: 800,000[4,20] 1: 1,000,000[15,19]$ and $1: 2,000,000[11,21]$. In seven articles $[11,12,22-24,26,28]$, the solutions were administered topically on the donor wounds. The injection levels of tumescent solution were at the subgaleal or areolar layer in 15 articles $[3,4,7,8,10,11,14-16,19,20,22,23,27,28]$, subcutaneous tissue in six articles $[2,6,9,12,13,18]$, and intradermal $[21]$ and additional dermal or subdermal tissue [11] in one article each. Four articles $[5,25,17,25]$ did not mention the injection level. Two articles did not use tumescent solution $[24,26]$.

The depth setting of the dermatome was less than 0.016 inches in 17 articles and 0.016 inches or more in seven articles [3,7, $13,14,19,24,28]$. Three articles $[6,8,9]$ did not mention the depth setting (Table 1 ).

There was only a single harvest or crop in 12 articles [5,9,13, $16,17,19-21,23-25,28]$, and single or multiple harvests in 15 articles. Two articles $[19,28]$ reported simultaneously harvesting the scalp skin and a dermal split-thickness graft. The interval of re-harvesting in the 15 articles with multiple harvests was 10 days or fewer in three articles $[4,8,14]$ and more than 10 days in five articles $[2,3,10,11,18]$. Seven articles did not mention the number of harvests (Table 1).

\section{TIME OF EPITHELIZATION}

The mean number of days of re-epithelization of the scalp donor site was less than 10 days in 13 articles, between 10 and 14 days in three articles $[3,15,23]$ and more than 14 days in two articles $[20,26]$. In nine articles $[6-9,12-14,21,27]$, the mean number of days was not mentioned (Table1).

\section{EARLY AND SYSTEMIC COMPLICATIONS}

Scalp donor infections were noted in seven patients $[3,7,11,20]$. Folliculitis at the scalp donor site was noted in 38 patients $[5,6$, $14-18,22,25,27]$. A concrete scalp deformity was observed at the scalp donor site in 18 patients [13]. Scab formations at the scalp donor site were recorded in 38 patients $[6,9,16,22]$. Nonhealing wounds were observed at the scalp donor site in 13 patients [25]. A transient moth-eaten appearance of the scalp donor site was noted in three patients (Table 1) [5]. Erythema at the scalp donor site can occur in all patients and was therefore excluded from the early complications. The early complication rate of the scalp donor site, calculated using the above-mentioned problems, was $3.82 \%$ ( 117 of 3,062 patients). As a systemic complication, blood loss requiring transfusion occurred in one patient [10], and five patients died due to sepsis [26].

\section{LATE COMPLICATIONS}

Alopecia after scalp skin harvest occurred in $4.74 \%$ of patients $(145$ of 3,062$)$ in 18 articles, while nine articles did not mention the proportion of alopecia after scalp skin harvest $[2,4,9,16,19$, $21,23,24,28]$. Five patients developed occipital alopecia due to pressure sores [22]. Hypertrophic scars were noted in five patients $[3,17,22,26,28]$. In four patients, scars were found due to harvesting beyond the hairline (Table 1) $[2,22]$. The late complication rate, calculated using the above-mentioned problems, was $5.19 \%$ ( 159 of 3,062 patients).

Twenty-seven patients with hair transfer in recipient grafts were noted in six articles (Table 1) $[4,9,11,12,18,21]$, and the rate of hair transfer to the grafted site was $4.23 \%$ (27 of $638 \mathrm{pa}-$ tients).

\section{DISCUSSION}

In this review of the literature, scalp STSG were mainly used in acute burn wounds in pediatric patients, and STSG were generally less than 0.016 inch thick. Skin grafts of major burn wounds required multiple harvests of the scalp with a short interval (approximately 10 days) between re-harvests.

Scalp donor sites for grafts that were 0.016 inches or more in thickness showed no alopecia and scarring in two $[19,24]$ of seven relevant articles. These reports suggest that scalp donor sites can be used to harvest thicker graft skins than other donor sites, without increasing the risk of complications.

Skin thickness varies with age, sex, and body area. Therefore, the depth setting on the dermatome should be determined by the thickness of the skin at the donor site. None of the reviewed articles mentioned the thickness of the scalp donor site. The author suggests examining the preoperative skin thickness of the scalp donor site using ultrasonography or other methods.

In many articles, it was difficult to use razors to shave patients' heads to allow subsequent hair removal. The author recommends shaving hairy areas of the scalp using electric hair clippers. Doing so cuts the hair shaft to a length of $1-2 \mathrm{~mm}$, making subsequent hair removal easier [20]. A graft contains numerous hair shafts that require removal before the graft is applied to the defect. This is most easily done by applying adhesive tape and rubbing the surface of the graft with a moist gauze swab. Alternatively, a pair of non-toothed forceps may be used to pluck out 
the hair shafts [3].

The shaving area was adjusted to the size of the required skin graft. For small grafts, the left or right parieto-occipital region was shaved. For larger grafts, both regions were used. In patients with male-pattern baldness or children, the hair line was traced to ensure that transplantable skin was only harvested in areas of excess hair growth. At the planned donor site, the cleared area, as indicated by skin markers, was infiltrated with modified tumescent solution until it became flat and expanded. The tumescent solution mainly contained normal saline or Ringer's lactate and was injected into the subgaleal or areolar level. If necessary, a tumescent solution could be mixed with adequate amounts of lidocaine (an anesthetic) or low concentrations of adrenaline (a vasoconstrictor). When STSG were harvested from the scalp without using tumescent solution, complications occurred frequently because the skin graft was too thick [26].

In two articles, technical mistakes in the depth setting of the dermatome led to the development of wide or global alopecia $[10,11]$. The blade angle, pressure, and speed applied to the scalp during skin harvest using a dermatome greatly influenced the actual thickness of the graft. Malpass et al. [29] showed a change in thickness from 0.12 to $0.42 \mathrm{~mm}$ using a dermatome depth setting of $0.2 \mathrm{~mm}(8 / 1,000 \mathrm{inch})$, with an average harvest graft thickness of $0.23 \mathrm{~mm}$, leading to the conclusion that the surgeon is the most relevant factor. McBride et al. [30] showed a wide range of thicknesses around the median, close to the depth setting of the dermatome. This range was so wide that it may challenge the assumption that STSG donor site wounds are uniform on the thighs of pediatric patients. The author suggests examining the graft or donor sites histologically after scalp skin harvesting. This can also be useful if it is necessary to perform several harvests. Before re-harvesting, it is necessary to wait until the scalp is completely healed.

The use of dermatomes with a depth setting of less than 0.016 inches showed higher early complication rates than the total early complication rate in five articles $[4-6,10,23]$ and higher late complication rates than the total late complication rate in eight articles among 15 articles [2,5,6,10-12,21,23]. Among the six articles $[3,7,13,19,24,28]$ that reported the relevant data, a dermatome depth setting of 0.016 inches or more showed a higher early complication rate than the total early complication rate in one article [7], a higher late complication rate than the total late complication rate in one article [3], and higher early and late complication rates than the total early and late complication rates in one article [13]. Overall, the rate of early and late complications did not seem to be related to the depth setting of the dermatome.

Dermatome depth settings of 0.016 or more inches resulted in alopecia $(4.3 \%, 24$ of 558 patients) in four articles $[3,7,13,14]$, but three articles $[19,24,28]$ did not report alopecia among 44 patients. Therefore, the occurrence of alopecia may not be related to the harvesting wound in the scalp, which is determined by the depth setting of the dermatome.

Two articles $[5,13]$ among the 12 articles that only reported single harvests showed higher complication rates than the total early complication rate (average, 3.85\%) and late complication rate (average, 5.19\%). Five articles $[4,6,7,10,25]$ among the 15 articles that reported both single and multiple harvests showed higher early complication rates than the total early complication rate, and nine articles $[2,3,6,8,10-12,22,26]$ showed higher late complication rates than the total late complication rate. Early complications did not seem to be related to multiple harvesting, but late complications did seem to show a relationship with multiple harvesting.

Brou et al. [8] noted that the overall incidence of alopecia after scalp harvest was $32 \%$ among 194 pediatric burn patients. The incidence of alopecia in the unburned scalp group $(\mathrm{n}=116)$ was only $13 \%$, compared to $61 \%$ of the group with concomitant burns of the scalp $(n=78)$. The incidence of alopecia in the unburned scalp group was statistically significantly $(\mathrm{P}<0.05)$ correlated with larger TBSA, greater burn index, a higher number of harvests, and a shorter mean elapsed time of harvests. A short single minimum interval between harvests was a significant contributing factor $(\mathrm{P}=0.001)$. The age difference was of no statistical significance. In the group with scalp burns, there were no statistically significant differences between patient variables. Concomitant scalp burn wound infection poses a high risk of contamination of the scalp donor site, and the resulting incidence of alopecia is thought not to be significantly related to any other patient-related variables. In addition, the use of the scalp as a donor site should be avoided in scalp burn patients.

The early complications described for scalp donor sites were scab formation, erythema, a transient moth-eaten appearance, wound infections, concrete scalp deformity, and folliculitis. Scab formation disappeared within 1 month after surgery. Erythema of the scalp donor site gradually improved for 1 year or more after surgery, and was related to the depth of the scalp donor site wound. A transient moth-eaten appearance improved during follow-up. Wound infections, folliculitis, and concrete scalp deformity require aggressive administration of sensitive antibiotics and treatment of the infected wounds. If these complications are not controlled, alopecia or tufted scar deformity may occur.

The late complications described included alopecia, occipital pressure sores, forehead scars, hypertrophic scars, tufted scar deformity, and technical mistakes of the harvest. Small lesions may not be noticeable. However, large lesions may require sec- 
ondary reconstruction. These late complications can be prevented through proper harvesting techniques, appropriate postoperative patient positioning, and early infection control.

MacLennan et al. [12] noted a moderate incidence of hair transfer (17\%, 18 of 109 pediatric patients). A higher incidence of hair growth was correlated with a larger burn size and multiple harvests of the same scalp donor site. However, no correlations were found with age, sex, time between harvests, or graft thickness. Approximately $33 \%$ of the hair transfer group (6 of 18 patients) had some degree of donor site alopecia.

Hair follicles in the telogen phase of the hair cycle cause apoptosis, and clubs in the telogen phase reach down to the hair bulge in the dermis layer; thus, if they are included in the grafted scalp skin, hair transfer can occur. Hair transfer is possible for pediatric patients with thick skin or after multiple harvests because their scalp is thinner than that of adults.

When the epidermis is damaged, keratinocytes from the epidermis and hair follicles surrounding the wound are mobilized to regenerate the epidermal barrier [19,31]. Fibroblasts of the dermal papilla and the dermal sheath of the hair follicle are multipotent mesenchymal stem cells [32]. Scalp donor wounds can be healed early without scar formation by interfollicular regeneration of the dermis and epidermis stem cells from hair follicles and adnexa $[28,33]$.

\section{CONCLUSION}

If STSG is required, scalp skin can be selected as the donor site, especially for skin thicker than 0.016 inch, and fewer donor site complications occur. It is safe to harvest the scalp skin after infiltration of the selected tumescent solution into the subgaleal plane. The thickness of the scalp skin varies greatly with age, and individual differences require measurements to be made before surgery. The surgeon should consider that grafted skin of various thickness can be obtained according to dermatome manipulation in the harvesting procedure. The total rate of early complications of the scalp donor site was 3.82\% (117 of 3,062 patients), and that of late complications was 5.19\% (159 of 3,062 patients).

Using a scalp donor site for STSG can prevent early and late complications if proper surgical planning, procedures, and postoperative care are performed.

\section{NOTES}

\section{Conflict of interest}

No potential conflict of interest relevant to this article was reported.

\section{ORCID}

SukJoon Oh

https://orcid.org/0000-0001-7793-6198

\section{REFERENCES}

1. Crawford BS. An unusual skin donor site. Br J Plast Surg 1964;17:311-3.

2. Taylor JW, Wilmore DW, Peterson HD, et al. Scalp as a donor site. Am J Surg 1977;133:218-20.

3. Kloti J, Pochon JP. Split skin grafts from the scalp. Prog Pediatr Surg 1981;14:111-22.

4. Berkowitz RL. Scalp: in search of the perfect donor site. Ann Plast Surg 1981;7:126-7.

5. Finucan T, Budo J, Clarke JA. Partial thickness scalp grafts: clinical experience of their use in resurfacing facial defects. Br J Plast Surg 1984;37:468-71.

6. Lesesne CB, Rosenthal R. A review of scalp split-thickness skin grafts and potential complications. Plast Reconstr Surg 1986;77:757-8.

7. Zingaro EA, Capozzi A, Pennisi VR. The scalp as a donor site in burns. Arch Surg 1988;123:652-3.

8. Brou J, Vu T, McCauley RL, et al. The scalp as a donor site: revisited.J Trauma 1990;30:579-81.

9. Martinot V, Mitchell V, Fevrier P, et al. Comparative study of split thickness skin grafts taken from the scalp and thigh in children. Burns 1994;20:146-50.

10. Gyger D, Genin B, Bugmann P, et al. Skin harvesting on the scalp in children: utopia or reality. Eur J Pediatr Surg 1996;6: 166-9.

11. Chang LY, Yang JY, Chuang SS, et al. Use of the scalp as a donor site for large burn wound coverage: review of $150 \mathrm{pa}-$ tients. World J Surg 1998;22:296-300.

12. MacLennan SE, Kitzmiller WJ, Mertens D, et al. Scalp autografts and hair transfer to the face in the burned child. Plast Reconstr Surg 1998;102:1865-8.

13. Carter YM, Summer GJ, Engrav LH, et al. Incidence of the concrete scalp deformity associated with deep scalp donor sites and management with the Unna cap. J Burn Care Rehabil 1999;20:141-4.

14. Barret JP, Dziewulski P, Wolf SE, et al. Outcome of scalp donor sites in 450 consecutive pediatric burn patients. Plast Reconstr Surg 1999;103:1139-42.

15. Mimoun M, Chaouat M, Picovski D, et al. The scalp is an advantageous donor site for thin-skin grafts: a report on 945 harvested samples. Plast Reconstr Surg 2006;118:369-73.

16. Khalid K, Tarar MN, Mahmood F, et al. Scalp as a donor site for split thickness skin grafts. J Ayub Med Coll Abbottabad 2008;20:66-9. 
17. Weyandt GH, Bauer B, Berens N, et al. Split-skin grafting from the scalp: the hidden advantage. Dermatol Surg 2009; 35:1873-9.

18. Farina JA Jr, Freitas FA, Ungarelli LF, et al. Absence of pathological scarring in the donor site of the scalp in burns: an analysis of 295 cases. Burns 2010;36:883-90.

19. Zakine G, Mimoun M, Pham J, et al. Reepithelialization from stem cells of hair follicles of dermal graft of the scalp in acute treatment of third-degree burns: first clinical and histologic study. Plast Reconstr Surg 2012;130:42e-50e.

20. Goldsztein H, Ort S, Roberson JB Jr, et al. Scalp as split thickness skin graft donor site for congenital atresia repair. Laryngoscope 2013;123:496-8.

21. Du Q Zhang T. Comparison of scalp and abdomen as splitthickness skin graft donor sites for aural stenosis repair. Eur Arch Otorhinolaryngol 2014;271:2159-64.

22. Wyrzykowski D, Chrzanowska B, Czauderna P. Ten years later-scalp still a primary donor site in children. Burns 2015; 41:359-63.

23. Roodbergen DT, Vloemans AF, Rashaan ZM, et al. The scalp as a donor site for skin grafting in burns: retrospective study on complications. Burns Trauma 2016;4:20.

24. Voorman M, Obourn CA, Frodel J. Facial defect reconstruction with scalp skin grafts. Facial Plast Surg 2017;33:419-22.

25. Kovacs M, Karsai S, Podda M. Superiority of occipital donor sites for split-thickness skin grafting in dermatosurgery: results of a prospective randomized controlled study. J Dtsch Dermatol Ges 2017;15:990-7.

26. van Niekerk G, Adams S, Rode H. Scalp as a donor site in children: is it really the best option? Burns 2018;44:125968.

27. Neuhaus K, Schiestl C, Adelsberger R, et al. Bold to do: bald to be? Outcomes decades after harvesting the scalp in burned children. Burns 2019;45:543-53.

28. Oh SJ. Simultaneous two-layer harvesting of scalp splitthickness skin and dermal grafts for acute burns and postburn scar deformities. Arch Plast Surg 2019;46:558-65.

29. Malpass KG, Snelling CF, Tron V. Comparison of donor-site healing under Xeroform and Jelonet dressings: unexpected findings. Plast Reconstr Surg 2003;112:430-9.

30. McBride CA, Kempf M, Kimble RM, et al. Variability in split-thickness skin graft depth when using an air-powered dermatome: a paediatric cohort study. Burns 2017;43:155260.

31. Levy V, Lindon C, Zheng Y, et al. Epidermal stem cells arise from the hair follicle after wounding. FASEB J 2007;21:135866.

32. Mistriotis P, Andreadis ST. Hair follicle: a novel source of multipotent stem cells for tissue engineering and regenerative medicine. Tissue Eng Part B Rev 2013;19:265-78.

33. Oh SJ. Dermatoscopy of scalp donor harvested thick splitthickness skin. Clin Surg 2019;4:2376. 